\title{
Length-weight relationships of seven fish species from the upper Pelus River, Kuala Kangsar district, Perak, Malaysia
}

\begin{abstract}
Length-weight relationships (LWR) are reported for seven fish species from the upper Pelus River, Kuala Kangsar district, Perak, Malaysia. This river is located in a remote area and supplies fishes for the aboriginal peoples. Fish samplings were conducted in three different seasons, the dry (June 2014), wet (August 2014), and moderately wet (April 2015). All samples were collected using fish electro-shocker and scoop nets with a $1 \mathrm{~cm}$ mesh size. A total of seven LWRs were unknown to FishBase, and four new maximum fish lengths were identified in the study.
\end{abstract}

Keyword: Length-weight relationships; Fish species; Pelus River; Kuala Kangsar district; Perak; Malaysia 